\title{
6
}

\section{Conventional stability operations at the battle group level in Iraq}

Anthony Rawlins

While Australia's military presence in Afghanistan ebbed and flowed, pressure was also on Australia to deploy land combat forces to support the coalition facing massive challenges in Iraq. On 16 July 2003, Operation FALCONER ceased and Operation CATALYST commenced, heralding a transition from a focus on combat operations towards the rehabilitation and reconstruction of Iraq.

In 2005 Australia committed the first of six conventional battle groups to security and stability operations in Iraq. This deployment was in direct response to broader US requests for increased coalition contributions to counter-insurgency operations. Australia's response focused on training indigenous Iraqi Security Forces to assume the lead for security under a new and democratically elected national government.

The decision to continue military operations remained a sensitive political issue. From the outset the decision to commit to the war in Iraq had never won bipartisan political or mainstream electoral support. ${ }^{1}$ The government's decision to remain committed was carefully considered,

1 The Opposition Leader at the time, Simon Crean, stated: 'Labor opposes your commitment to war. We will argue against it and we will call for the troops to be returned.' House of Representatives debates, 18 March 2003, p. 12512, www.aph.gov.au/About_Parliament/Parliamentary_Departments/ Parliamentary_Library/pubs/BN/0910/ParliamentaryInvolvement (retrieved 31 March 2020). 
finely calibrated and specifically messaged: this was to be a transition from combat-focused operations reflecting ongoing coalition progress in Iraq. ${ }^{2}$ Previously the government had sought to justify military commitments on the basis of Iraq's breaches of UN resolutions, catalogued in United Nations Resolution 1441. As counter-insurgency operations deepened, coalition casualties mounted, and the likelihood of discovering a WMD 'smoking gun' diminished, debate about the value and legitimacy of continued military participation escalated.

With the announcement of an imminent withdrawal of Dutch forces from Iraq's southern provinces, the government now contemplated a US request for an Australian force element to replace them. On 22 February 2005, Prime Minister John Howard announced the deployment of a conventional battalion-sized group to Al Muthanna Province, designated the Al Muthanna Task Group (AMTG). Its mission was to provide a stable and secure environment for the Japanese Reconstruction and Support Group undertaking humanitarian, engineering and reconstruction tasks in the area, and to assist in the training of Iraqi army units in the province. ${ }^{3}$ Working in support of the Interim Iraqi Government, AMTG-1 would provide a visible and tangible Australian contribution to multinational efforts to develop a more secure and stable Iraqi nation-state.

Over five subsequent evolutions, this task group, later redesignated the Overwatch Battle Group (West) (OBG(W)), undertook a variety of activities to expedite the capacity of Iraqi Security Forces and local government to buttress local security, support civic control and deliver good government. Australian forces oversaw the inaugural and largely successful transition of Al Muthanna and Dhi Qar provinces from coalition to Provincial Iraqi Control, the first two provinces in Iraq to achieve this milestone. Australian forces then transitioned into a loosely defined but ostensibly supportive 'operational overwatch' configuration until the last Australian battle group withdrew in 2008. Despite numerous engagements with adversary groups - particularly the Jaysh al-Mahdi militia (a group that emerged in 2003 led by firebrand Shia cleric Muqtada al-Sadr)—no Australian soldier from any contingent was killed in action. This combination of progressive Iraqi success, zero fatalities and American political praise for Australia's contribution has since facilitated generally positive mainstream analyses of Australian efforts on Operation CATALYST. ${ }^{4}$

2 Blaxland, The Australian Army from Whitlam to Howard, p. 218.

3 Department of Defence, Annual Report 2004-05, Department of Defence, Canberra, 2005, p. 161, www.defence.gov.au/annualreports/04-05/downloads/0405_dar_10_full.pdf(retrieved 31 March 2020). 


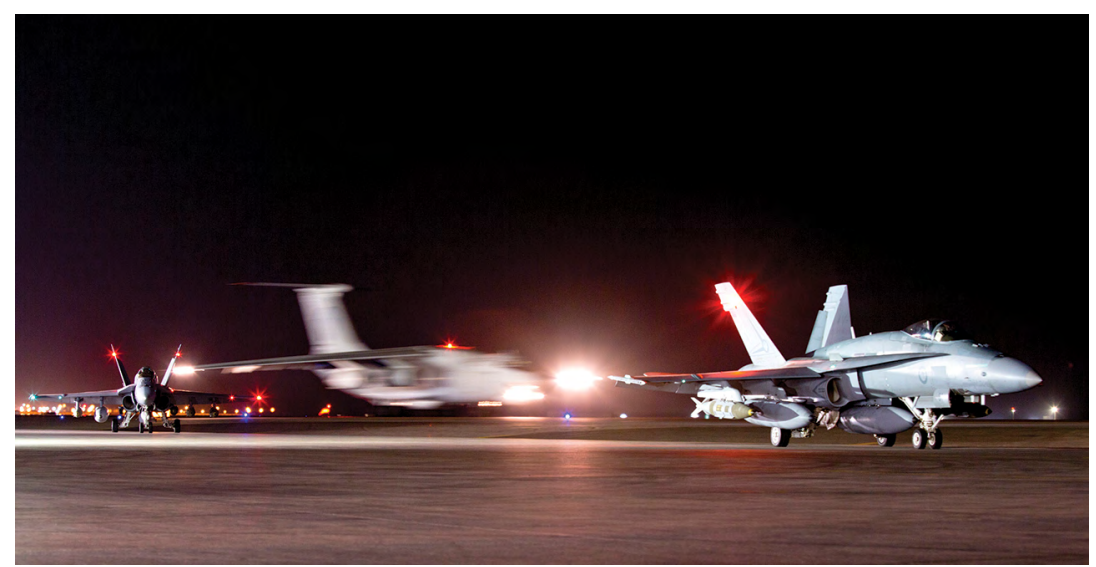

Royal Australian Air Force F/A-18A Hornets prepare to depart on a mission to strike a Deash headquarters compound in Mosul, Iraq, from Australia's main air operating base in the Middle East region, 2016.

Source: Courtesy of the Department of Defence.

In contrast, the academic commentary has been more probing and the praise less effusive. ${ }^{5}$ Analysis and critique has focused more on the motives and means by which this carefully nuanced military contribution achieved its professed political and strategic objectives. Although the general consensus suggests that Australia adroitly managed its participation and achieved its desired strategic outcomes at very little cost, some have contended that at the tactical level, Australia's reputation as a 'heavy lifter' in the coalition community actually suffered. Within the Australian Army itself, a parallel and equally critical dialogue appraising the means by which senior leadership chose to manage the political-strategic military requirement for government has also been evident.

This academic dialogue formed the touchstone for my presentation to the 'War in the Sandpit' seminar at Gallipoli Barracks, Enoggera, on 12 May 2017. Invited to speak as a former Commanding Officer of Overwatch Battle Group (West)-2 (OBG(W)-2), I chose to recount my experience of the deleterious impact of strategic-tactical dissonance during this deployment; that is, the subtle but visceral impact on the practice of mission command emanating from uncertainty as to the strategic objective of the mission. I settled on this approach following near-unanimous concurrence among six the AMTG and OBG(W)

$5 \quad$ Ibid., pp. 244-5. 
commanders that higher-order strategic imperatives—specifically, a clear national intent-had not been adequately or accurately communicated to the tactical level of command. The consequences, certainly in my own personal experience, manifested in some strategically counter-intuitive and tactically debilitating outcomes unlikely to have been evident at the highest levels of command, but which I now recognise as needing to be highlighted as containing important lessons for the future.

My observations, assessments and deductions on this issue, presented to many academic, military and political leaders at the seminar, proved polarising. Not surprisingly, in the post-seminar wash-up, my observations seemed to resonate favourably with those who operated at the tactical level but attracted scepticism amounting to outright rejection the more senior the stakeholder involved was in the chain of command, particularly so the more personal their involvement in the planning or execution of Operation CATALYST. Some media personalities saw my assessments as a potential smoking gun, seemingly confirming their long-held suspicions of duplicity between the government's declared and unstated motives for engagement in Iraq and its commitment to coalition efforts. Despite what some might have thought, my motives were neither to denigrate my military superiors, criticise government capacity or commitment to furthering Australia's national interests, nor the means chosen to achieve them. Nor was it to suggest that Australia should have committed more heavily to combat operations during Operation CATALYST.

Rather, my intent-which can be more fully outlined in this chapterwas to examine in greater detail the means by which our military elected to exercise command and control, and apply the concept of mission command in the conduct of security and stability operations in Iraq. Not surprisingly, in light of my own and most of my counterpart commanding officer experiences, this examination has precipitated a reasonably critical view of our command and control architecture, emanating from what I do believe to have been the highly politically charged and nationally sensitive nature of this operation.

In attempting to understand why a restrictive and directive means of national command and control was employed, undermining the practice of mission command at the tactical level, I have relied upon third-party assessments. I must emphasise that I was not privy to the discussions and debate at the strategic and operational levels that would no doubt have informed the development of this command and control system. 
Very few at the most senior levels of command would have been party to these discussions. Nevertheless, in my own mind, the search for reasons is important, given that the tenets of mission command were both doctrinally prescribed and professionally accepted in the Australian Army at that time, yet were seemingly either consciously or subconsciously discarded during many of the task or battle group deployments.

In the final analysis, much (I now suspect) revolves around the question of whether there was an express or implied direction for Australian battle groups to limit operational activity to avoid casualties. To this day I can neither unequivocally confirm nor deny whether this was the case; although it was certainly a topic of hot discussion within most contingents, no such direction (to my knowledge) has been confirmed as either an express or implied requirement. At best my personal experience and discussion with other tactical commanders confirms that remained a metaphoric 'elephant in the room' for most contingents deployed on Operation CATALYST.

This chapter therefore allows me to amplify the position put forward in my verbal presentation to the 'War in the Sandpit' seminar. It outlines my personal understanding of the background, objectives and nature of tactical operations in Iraq during Operation CATALYST. It leverages third-party accounts of the strategic and operational decision-making processes to discover what the national strategic intent might have been, which would have informed force design and development of a command and control architecture to give best effect to the political objective. It is my personal view, and that of most of my counterpart commanders on Operation CATALYST, that the command and control architecture chosen and employed was non-doctrinal and suboptimal for prosecuting contemporary operations. Our recounted experiences suggest the exercise of mission command at the strategic through to tactical levels was frequently undermined by an unfamiliar national command framework. This chapter seeks to discover the reason for this and in so doing highlights a potential lesson for Army: the importance of communicating strategic intent down to the tactical level as an essential prerequisite for the practice of mission command on complex operations. 


\section{The strategic context}

Essential reading for anyone interested in Australia's military activities in Iraq is the abridged history and analytical study of the war in Iraq by Albert Palazzo, The Australian Army and the War in Iraq: 2002-2010. The Australian Army directed Professor Palazzo to undertake this study in order to critically review Australia's involvement in this contemporary campaign for future learning. His work, heavily redacted for release at the unclassified level, still provides a comprehensive history andfor many - a broad-ranging insight into the operational and strategic considerations at play at the time.

His study highlights that the commitment of Australian forces to Iraq, from the commencement of combat operations through to stability and security operations, remained a politically sensitive issue for government. The conduct of this seminar confirms that many in the policy and academic community are comfortable with recognising that a principal determinant in Australia's decision to commit to the war in Iraq was a calculated intent to enhance the strategic relationship between Australia and the United States. The seminar served to further confirm the strategic intent and outcome suggested by Palazzo in the Lowy Institute's blog, Interpreter:

Australia joined the war to advance its own policy objective: to improve its relationship with its great power protector. It achieved this goal with great skill and at very little cost, and showed that it is possible for a junior partner to advance its strategic interests within a coalition dominated by a great power. For Australia, what mattered most was not what was happening in Baghdad but in Washington. ${ }^{6}$

6 A. Palazzo, 'The making of strategy and the junior coalition partner: Australia and the 2003 Iraq War', Infinity Journal, art. 6, vol. 2, no. 4, 2012, pp. 27-30, quoted in Palazzo, 'We went to Iraq for ANZUS', Interpreter, 25 March 2013, www.lowyinstitute.org/the-interpreter/we-went-iraq-anzus (retrieved 31 March 2020). 


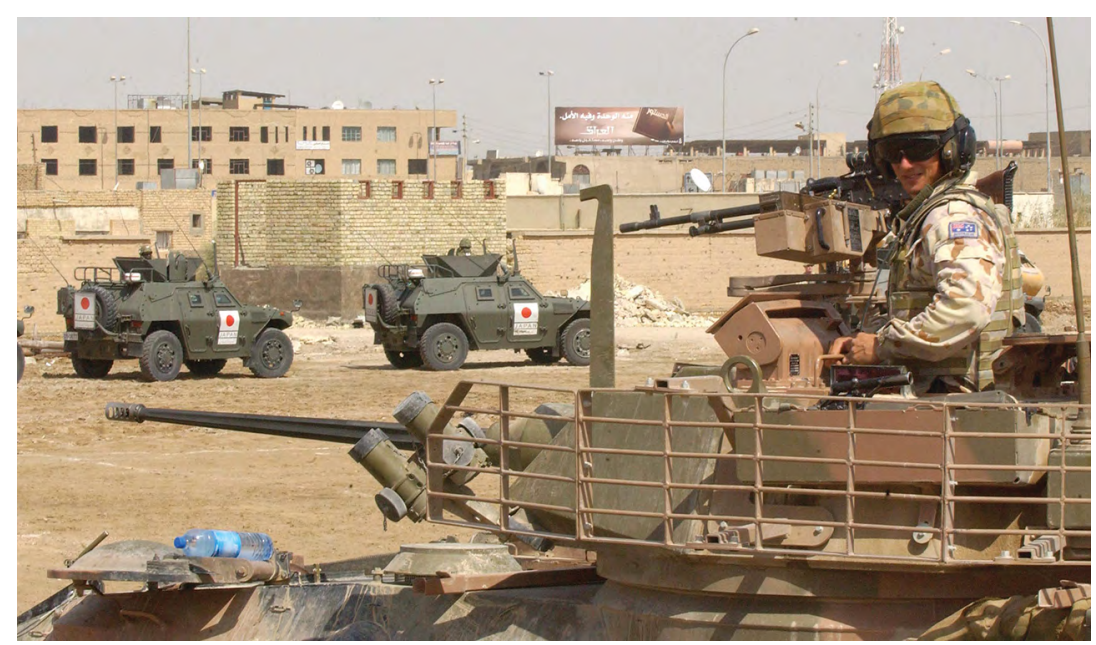

A trooper from the 2nd Cavalry Regiment provides security to Japanese Iraq Reconstruction Group convoy vehicles in As Samawah, 2005.

Source: Courtesy of the Department of Defence.

This policy objective, coupled with the political landscape, would have heavily influenced military planning, force design and the selection of operational areas for Australian forces. It would also have informed mission specification, pre-deployment training and the overarching national command and control architecture. In contrast to the more combat-oriented counter-insurgency operations being undertaken by US and British forces, the Australian mission set was carefully calibrated to enliven the strategic focus on provincial reconstruction and rehabilitation. Nevertheless, given the potential sensitivity of the electorate to Australian casualties, design and provisioning of the force ensured that it would be capable of defending itself in combat operations against any conceivable adversary in its area of operations.

The prescribed area of operations and mission set for the inaugural AMTG deployment clearly reflected these strategic considerations. In the largely peaceful province of Al Muthanna, AMTG-1 was to provide a stable and secure environment for the Japanese Reconstruction and Support Group undertaking humanitarian, engineering and reconstruction tasks in southern Iraq, and to assist in the training of Iraqi army units. The force, a 'square' battle group comprising a light armoured (cavalry) squadron and a protected motorised infantry company, along with combat support and combat service support company-sized subunits, was deemed more than capable of overmatching expected levels of opposition in the area. 
However, during the third AMTG rotation, the Japanese force withdrew from theatre as Al Muthanna transitioned to Provincial Iraqi Control. This transition in July 2006 marked the formal handover of primary security duties for the province from coalition forces to the Iraqi Government and its indigenous security forces. With this change, the ostensible and predominant function of Australian military forces in Al Muthanna had been removed. AMTG-3 therefore relocated to Ali Air Base, Tallil, in the neighbouring province of Dhi Qar. By way of new function, the task group was now assigned the rather ill-defined task of operational overwatch of Al Muthanna Province, which still entailed continued training and development of Iraqi Security Forces under the capstone program known as Mentor, Monitor and Train (M2T).

Dhi Qar was the next province to transition to Provincial Iraqi Control on 21 September 2006, as the Italian contribution previously overseeing provincial security withdrew in the following month. In response to coalition (predominantly US) representations to replace them, Australia agreed additionally to assume operational overwatch of Dhi Qar Province, and with this expansion and consolidation of duties the AMTG was then retitled the Overwatch Battle Group West (OBG(W)), with AMTG-3 becoming the inaugural $\mathrm{OBG}(\mathrm{W})-1$.

This change in title reflected a fundamental change in the mission and objectives of the Australian force, with the battle group being more heavily focused on training and developing the capacity of the Iraqi Security Forces while maintaining a preparedness posture to provide support if the security situation degenerated beyond their capacity. However, the simple reality is that this 'intervention' posture was more illusory than real, crafted more to bolster the confidence of the local Iraqi Security Forces than to backstop them militarily. Operational overwatch was also cleverly conceived to present a positive strategic picture of Australia as a coalition partner engaged in 'heavy lifting', particularly as the insurgency in Iraq grew increasingly virulent, although the scale and intensity of counterinsurgent activities in Al Muthanna and Dhi Qar provinces remained well below the national average.

I describe the mission set of 'overwatch' as something of a facade on the basis that the provision of combat support to the Iraqi Security Forces was really nothing more than a fictional construct, and the provision of combat support resided well outside the decision authority of the local battle group commander. Activation required a complex, lengthy and 
largely ill-defined series of approvals from local to national Iraqi, coalition and then Australian governmental approval chains. It was made clear to successive tactical commanders that Australia would approve such a request only on formal application from the government of Iraq to the Australian Government, requiring that government prove that the situation outstripped the capacity and capability of national security resources. Iraqi Government inability or unwillingness to commit national resources would not constitute sufficient reason for the battle group to engage in supportive combat operations. In a hypothetical crisis, this high threshold for action meant that any Australian intervention would have come late, following the commitment and overmatch of all national and other regional coalition forces in order to stabilise the situation before it spiralled out of control and generated a public affairs disaster for the coalition.

This arrangement meant that there was never any conceivable likelihood of the battle group being able to support local Iraqi forces constructively and decisively in combat operations to maintain stability in the province, at least not before it had escalated out of control, requiring a larger and more immediate coalition intervention to stabilise the situation.

This significant practical impediment was certainly not reflected in the Multi-National Division - South East (MND-SE) mission orders for the Australian force. In order to manage British (and potentially also US) expectations, it meant that the bulk of $\mathrm{OBG}(\mathrm{W})$ activity focused on supporting activities to maintain stability in the provinces, rather than actively pursuing destabilising elements. This translated into daily activity sets including Key Leadership Engagement (KLE) with local leaders, collective and individual training of provincial leaders and Iraqi army elements, force protection of coalition forces and installations, and intermittent support to various local Provincial Reconstruction Teams (PRTs). These efforts have been accurately characterised as 'preventing the insurgent's cause from gaining purchase in the prevailing society' rather than on combat operations against the enemy. ${ }^{7}$ It proved-in large measure- to be a successful approach, although it was periodically upset by events occurring in other parts of Iraq, which served also to destabilise the local security situation.

7 Blaxland, The Australian Army from Whitlam to Howard, p. 242. 
It is a matter for historical record that, over time, the insurgency in Iraq grew ever more emboldened, increasingly contesting the authority and control of national and provincial governments and the capabilities of the Iraqi Security Forces. This national trend periodically affected southern Iraq, most notably during coalition counter-insurgent surge periods in central and northern Iraq. It translated into more dangerous operating conditions for several $\mathrm{OBG}(\mathrm{W})$ rotations, particularly in the conduct of movement, patrols and KLE in Dhi Qar Province. It was frequently asserted that the former Italian contingent had negotiated an agreement or 'detente' of sorts with the Jaysh al-Mahdi militia in Dhi Qar Province. In exchange for some measure of financial assistance, the Italian contingent could operate without the militia contesting their presence. This arrangement was never confirmed, but it goes without saying that a 'contract' of this nature would never have been contemplated by-let alone authorised for-Australian forces operating in Iraq. In accordance with the operational mission specified in orders from Headquarters MND-SE, OBG(W)-2 thus began to expand its capstone overwatch and training activities into Dhi Qar Province, bringing it into closer contact with insurgent forces frequently using Dhi Qar as a 'rest and recreation' locale from insurgency activity in other parts of Iraq.

This seems to have been the catalyst for increased scrutiny and directive control from the national command chain, as OBG(W)-2 began to orient towards the operational overwatch and friendly force protection components of the mission in response to local assessments of security conditions. This reorientation inevitably brought the battle groups into closer contact with the Jaysh al-Mahdi militia, the stakeholder most likely to contest their presence. Attacks on coalition logistic convoys and indirect fire attacks against the Tallil Air Base also began to increase at this time. This deterioration in provincial security conditions and the greater level of insurgent activity in Dhi Qar Province might have tripped risk sensitivities in the Australian national chain of command. This in turn gave rise to a perception of increased scrutiny and intervention in tactical decision-making by the Australian headquarters of Joint Task Force 633 (JTF 633), ostensibly to assess and regulate tactical activities in Dhi Qar in accordance with Australian national intent.

Certainly, during the OBG(W)-2 deployment, the Australian national commander in JTF 633 now specified a requirement for advance notification of all tactical activities through provision of plans and orders 
to the national headquarters in Baghdad. This gave rise to frequent episodes of Commander JTF 633 reserving (and frequently exercising) the right to veto tactical activities, including patrols aimed to counter improvised explosive devices (IEDs), interdicting the main coalition supply route from Kuwait to Baghdad, and clearing patrols to known rocket launch sites. This veto frequently took the form of directing the commanding officer to canvas other coalition forces on Tallil Air Base to execute these activities, all well understood to be within the Australian mission remit according to operational orders from Headquarters MND-SE. This approach generated significant tension between myself and the commander of JTF 633, as I continually asserted that these tasks were well within our mission set. It also generated tension between the $\mathrm{OBG}(\mathrm{W})$ and local coalition force elements, given their loss of confidence in Australian capability and resolve, which also gravely wounded morale within the Australian contingent. The question of just why we were frequently precluded from executing approved mission sets for which we had been trained and assessed as mission capable during our final Mission Rehearsal Exercise was the source of great confusion among the contingent.

This dissonance between implied strategic intent and tactical freedom of action during my deployment suggested a critical omission in the national command architecture-a failure effectively to communicate national intent or strategic objectives from which we could purposefully orient our tactical actions. We understood our tactical mission and tasks articulated in the operations order from Headquarters MND-SE, which was provided in the traditional, well-understood coalition mission orders format. These orders expressly contemplated combat action against the insurgency in support of provincial stability and security, support to friendly forces in contact, and integral force protection activity. To my recollection, each and every task and battle group before ours had extensively trained to this mission set during its Mission Specific Training and Mission Rehearsal Exercise before deployment. These were enduring tasks, and while they were articulated in the UK-led Headquarters MND-SE operations order, they had been ratified by previous Australian national command chains so as to inform Mission Specific Training and Mission Rehearsal Exercise training and certification. 
The Australian national command also intervened in the tactical activities of other task and battle group contingents. This was presumably to ensure that tasks allocated in mission orders from Headquarters MND-SE did not breach or contravene Australian national interests. This in theory should not have presented a problem, as this is the express role and function for a national command entity in Australian operational doctrine. The problem was manifest in its execution rather than the theory.

Herein lay the essential problem for myself and many other tactical commanders attempting to execute operational orders from Headquarters MND-SE: what were Australia's national interests in southern Iraq? Without this clear articulation at the tactical level of command, the only means by which Australian national interests could be properly interpreted, preserved and/or protected was through incessant intervention by the national command chain to authorise, modify or veto tactical activities based upon an isolated and segregated assessment of strategic intent. This translated into a highly variable level and poor understanding of the risk management frameworks of each national commander.

\section{The criticality of communicating national intent}

Australian military doctrine itself highlights that without clear articulation of intent, the foundational basis for the application of mission command will be absent. ADF doctrine directs commanders to make sure that subordinate commanders understand the higher commander's intent, their own missions and the operational context before planning tactical activity. Articulation of intent forms the conceptual basis for mission command, as subordinates can then be told what effect they are to achieve and the reason it is necessary. Their superior commander will tell them what to achieve, but should not tell them how to achieve it-the 'how' is the preserve of the tactical commander, who is acknowledged as being in the best position to read and understand local conditions and situational variables. ${ }^{8}$

8 Land Warfare Doctrine 0-0, 'Command, Leadership and Management', chapter 2, section 2-2, 10 June 2008, para 12. 


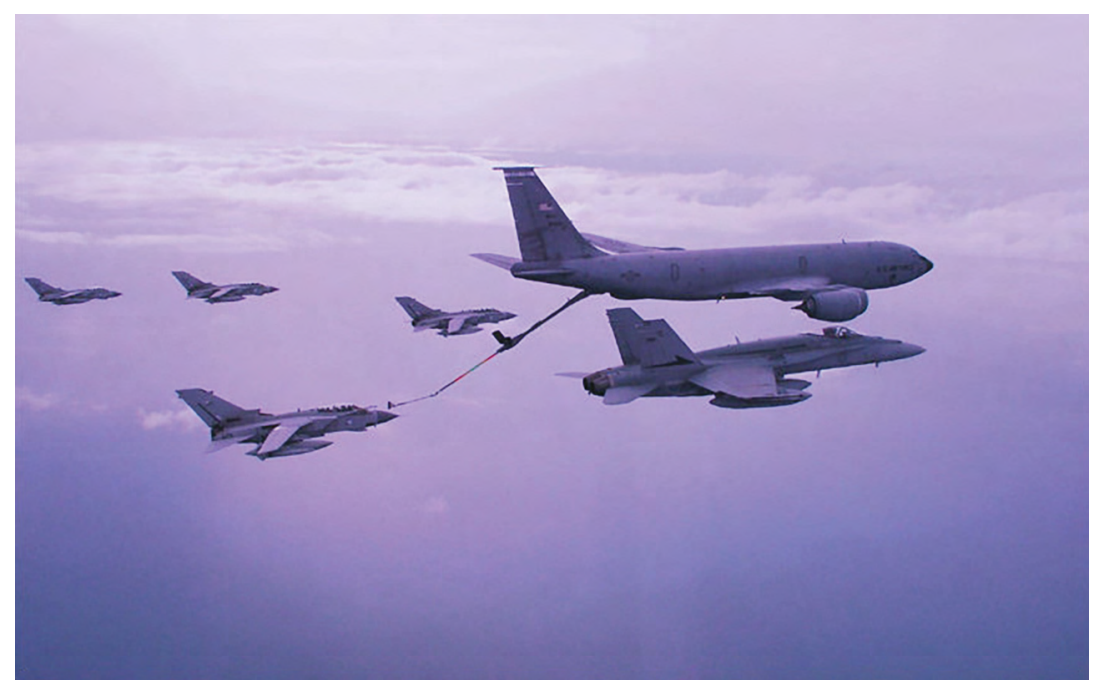

An F/A-18 waits its turn to refuel over Iraq during Operation Falconer, 2003.

Source: Courtesy of the Department of Defence.

The experiences of Australia's tactical commanders on Operation CATALYST suggest that this most basic of doctrinal stipulations was at best only partially enacted, often in an ad hoc and informal manner. The commanding officer of the first Al Muthanna Task Group (AMTG-1), then Lieutenant Colonel Roger Noble, recalls that the strategic intent for the mission was verbally communicated to him by both the Chief of Defence Force (CDF) and Chief of Army (CA) before his deployment. However, written versions of Australian strategic and operational orders were neither drafted nor made available until well into the AMTG-1 deployment. Given that he recalls writing his own mission orders in the absence of anything other than verbal context, it is likely that national orders were retrospectively drafted to conform to the tactical orders he had written. By way of comparison, Noble recalls the operational orders provided by the higher coalition headquarters (MND-SE) to be both precise and well articulated, with clear intent provided in both written and verbal media. Somewhat incongruously, he recalls a lack of interaction with the Australian theatre commander, Chief of Joint Operations (CJOPS), until such time as his first visit during the deployment. This suggests either an implicit acceptance that coalition orders were compatible with Australia's strategic intent or, alternatively, that either the tactical commander or Australian national commander would be required to manage and ameliorate any inconsistency on the ground. 
AMTG-1 was the inaugural deployment and at short notice, and therefore an element of 'catch-up' could be countenanced. Subsequent commanders did not receive a similar level of pre-deployment interaction with either CDF, CA or CJOPS, thereby precluding this personal conveyance of strategic intent. In the absence of this personal interaction and clear written articulation of national intent, most tactical commanders have expressed different levels of confidence that the strategic intent was sufficiently discoverable or could be properly implied. Of those most confident that the strategic context and command intent was implicitly discernible, the commanding officer of AMTG-3/OBG(W)-1 recalls:

$[R]$ eviewing the intent that I drafted as part of our in-theatre review (completed at the end of the first month in theatre) it was pretty clear that I understood the strategic aim ... In terms of Australian interests it was clear to me that we had an 'enabling role' and that the confluence between tactical mission and Australian interests lay in us providing an 'overt demonstration of relevance and the continual delivery of positive outcomes or effects'. The Task Group had 'to provide a balanced, agile and highly relevant military response'. The mission was on the nose politically and the US was in the midst of the 'cut and run' debate so it was clear that at the political-strategic level our masters were searching for answers and leaning very heavily on the military to come up with a solution. This was clear across the board within the coalition chain of command. I knew I wasn't going to get any coherent guidance and decided to embark on our own approach[,] building on the conceptual work done by AMTG-2.?

Other commanders, however, cite lower levels of confidence in attempting to discern the strategic intent in light of the evolving political context. This was my own personal experience. Despite the extensive mission specific training and Mission Rehearsal Exercise regime, I remained unsure as to what express or implied strategic caveats or limitations would circumscribe my tactical freedom of action. I therefore undertook a self-funded trip to Canberra during my pre-deployment leave in order to gain a better understanding of the strategic context and any national caveats from our strategic headquarters in Canberra. I particularly wanted to confirm the veracity of rumours circulating in our mounting base that we were to avoid casualties at all costs.

9 Discussions with author. 
I therefore organised an impromptu visit to Military Strategic Commitments at Russell Offices in Canberra. None of the senior appointments were available for me at the time I visited. In speaking to the relevant desk officer for Operation CATALYST, asking for advice as to what I needed to do to meet the strategic intent and what I needed to avoid, the response was disappointingly blithe and vague. The advice was simply 'Just don't $\mathrm{f}^{*} \# \mathrm{k}$ it up' [sic]. When I asked what this actually meant, I was told that I would very quickly discover what I was doing wrong if I 'skied off-piste'. At his level of authority and understanding, the desk officer simply could not cogently articulate what sort of things were 'on' and what was 'off-piste'. It was not very reassuring, but by the same token I was relatively comfortable that the pre-deployment training had provided me with an operative understanding of what we were there to do, and what tools and tactics were available to me as a commander in seeking to execute this amorphous 'national intent' in the absence of specific national orders.

Other tactical commanders recount a similar personal requirement to determine implied strategic intent through their mission analysis process. The provision of coalition operational orders during pre-deployment training provided a solid understanding of coalition operational intent. However, Australia's military orders tended to focus almost exclusively on the administrative or procedural aspects of constituting, concentrating and deploying the force into theatre. Reassurance was derived from the assertion that operational orders from Headquarters MND-SE had been vetted at the Australian theatre command level, and it was assumed that instructions to overcome any incongruence would be articulated in individual directives, national orders from Headquarters JTF 633 or in the CJOPS campaign plans. As a matter of doctrine, they would also be addressed 'on occurrence' by the national command chain in theatre-the raison d'être for a national commander in theatre. But the lack of a clear, cogent statement of national intent through the doctrinally accepted orders process clearly complicated the pre-deployment preparation of respective force elements. A heavy focus on the administrative and governance aspects of deployment served more to distract rather than assist tactical commanders in this respect. The commanding officer of AMTG-3/OBG(W)-1 recalled: 
The hierarchy of military orders didn't flow naturally within the coalition but, as mentioned before, I was conscious of the dissonance within the coalition and also of the governance focused (and therefore limited utility) of national directives. By way of example, the mounting order out of Headquarters 1st Division came too late to make any difference and the deployment order arrived a day after our advance party had left. ${ }^{10}$

This diffuse process also resulted in a lack of discernible communication as to any national caveats or 'red cards' to the tactical commanders through Australia's operational chain of command, at least not before interaction with the national commander in theatre.

However, if the national intent or caveats took time to discern for Australia's tactical commanders, there was little doubt that-over time-they came to be well understood by the higher coalition headquarters. In the short period in the transition between the first and second AMTGs, it appears that Headquarters MND-SE had already determined that national strategic intent was curtailing the Australian tactical commander's freedom of action. This interpretation was not complimentary, but it was generally understanding of the circumstances in which the Australian force element had to operate. The Commanding Officer AMTG-2 lamented:

I never received orders. I just took Roger's orders and typed a ' 2 ' over the ' 1 ' and no-one noticed. By the time I arrived in theatre, the Brits had given up on us as far as contributing to their plan. The British Brigade Commander in Basra gave me his Brigade operational orders and asked me to fill in the blanks for AMTG-2-this is true! As there was no formal direction from Australia, I therefore made it up. No one ever took me aside and told me what the actual (not for public consumption) reason for us was for us being in Iraq. It certainly wasn't to defeat anti-Iraqi Government forces and it was also evident that the Japanese weren't totally incapable of looking after themselves. I had a conversation with Chief of Army just before we left and confirmed the real reason, but it wasn't until day 3 on the ground in theatre when I think when I realised that all we could do was stuff things up ... As-Samawah was as good as it was ever going to get! ${ }^{11}$

10 Discussions with author.

11 Discussions with author. 
As foreshadowed earlier, this absence or informality in the articulation of strategic intent was accompanied by a bureaucratic and forensic involvement in the administrative aspects of the deployment by various headquarters in the national command chain. According to the commanding officer of AMTG-3/OBG(W)-1:

the operational concepts were developed by us and briefed to all of the supporting commanders and also those in our tactical chain, and they were agreed without too much fuss. Fortunately, no one else was doing it at the time and, although some train-spotting [i.e. higher-level engagement with the details of our planning] occurred, it was inconsequential. Orders were largely written by us for insertion into the relevant orders (mainly divisional orders). HQ JTF 633 orders were largely administrative. ${ }^{12}$

The commanding officer of AMTG-2 similarly recalls an absence of articulation of national strategic intent, coupled with an overbearing and unhelpful focus on administrative control driven by internal military politicking:

In the early days, AMTG was to be a 12-month commitment with two six-month tours, the 2nd Cavalry Regiment being first. I was involved in much of the early discussions and planning as it was obvious to us in 1 Brigade that the follow-on force would have to be 5/7 RAR. What I didn't factor on was a senior officer in Headquarters 1 Division wanting a 3 Brigade unit to go next. It meant that for the next four months, I had no authority to spend money or do anything really to prepare the force (training, equipment and even my reconnaissance) and everything I did was through begging, borrowing, stealing and bluffing. I had to fight constant little 'pissant' battles to get simple requests filled like automatic sniper rifles, and if it wasn't for Chief of Army showing such an interest in us and thus being available for me to speak directly to when he visited, I wouldn't have got the very little I asked for. In the end, I was described by a colonel in Army Headquarters as a 'typical whinging CO'. I also had to deal with personnel and families who wanted to know what was going on, plans, career courses, postings, and the like. I rolled the dice and bluffed through it, telling everyone it was up to us to do. ${ }^{13}$

12 Discussions with author.

13 Discussions with author. 
These experiences suggest that there were significant deficiencies in the articulation of intent at the operational level in Australia's chain of command, potentially owing to a more incumbent focus on the administrative aspects of preparing and deploying operational contingents. Nonetheless, it seems clear from a subsequent reading of Palazzo's study that Australia's strategic leaders had actually developed and were maintaining a high level of strategic unity. This seemed to have been well in place during the inaugural Australian deployment, with the commanding officer of the first AMTG recalling:

[The Chief of the Defence Force] articulating his intent and then reinforcing this during his visits meant that it worked-without that we would have deployed with no orders. Actually, both the Prime Minister and Minister for Defence were also very clear on their intent when they visited us. ${ }^{14}$

Although in Palazzo's estimation politico-military unity might have endured throughout Operation CATALYST, the articulation of national intent and military strategic objectives down through the operational to tactical levels clearly seems to have fallen away in subsequent rotations. This might have been because the political and military strategic leadership remained confident that the initial parameters had been set by the first AMTG deployment; therefore only minimal ongoing dialogue was required to maintain a steady state. Alternatively, it might have been that as the tactical situation on the ground became more dangerous, particularly with the assumption of responsibilities in Dhi Qar Province, the risk of Australian casualties demanded closer scrutiny and control of tactical activities by the Australian national command. Irrespective of either possible motivation, what resonates most strongly is a definitive procedural failure to convey the strategic intent-the fundamental strategic context-down to the tactical level as the tenets of mission command suggest is essential for unity of effort.

14 Discussions with author. 


\section{Intent and the practice of mission command}

Articulation of command intent, from strategic down to tactical levels, forms a bedrock principle of the philosophy of mission command. Without this clear articulation, unity and synchronisation of effort suffer:

Mission command and control relies on the use of mission tactics in which seniors assign missions and explain the underlying intent but leave subordinates as free as possible to choose the manner of accomplishment. Commanders seek to exercise a sort of command by influence, issuing broad guidance rather than detailed directions or directives. The higher the level of command, the more general should be the supervision and the less the burden of detail. Commanders reserve the use of close personal supervision to intervene in subordinates' actions only in exceptional cases. Thus, all commanders in their own spheres are accustomed to the full exercise of authority and the free application of judgment and imagination. Mission command and control thus seeks to maximize low-level initiative while achieving a high level of cooperation in order to obtain better battlefield results. ${ }^{15}$

Australian Defence Doctrinal Publication 0.01 (ADDP 0.01) and Land Warfare Doctrine 0-0 (LWD 0-0) are typical of the genre in that they restate most of the universally accepted prerequisites for the successful application of mission command. These include the concepts and precepts of doctrine, reliability, trust, understanding and risk. ${ }^{16}$ Western military doctrine specifies that for mission command to be effective, each tenet must be well understood and accepted at all levels of command, and then vigorously enacted in practice.

However, during Operation CATALYST, the philosophy of mission command was not formally entrenched as the joint command philosophy for the conduct of operations by deployed forces. The ADF's capstone command and control publication in effect at the time was Australian

15 United States Marine Corps, Command and Control, Doctrine Publication 6, Department of the Navy, Washington, DC, 1996, pp. 109-10, www.marines.mil/Portals/1/Publications/MCDP\%206. pdf?ver=2019-07-18-093633-990 (retrieved 31 March 2020).

16 Land Warfare Doctrine 0-0, 'Command, Leadership and Management', chapter 2, section 2-2, 10 June 2008, para 13. 
Defence Force Joint Operational Command and Control, ${ }^{17}$ issued on 14 December 2001, operative as interim command and control doctrine until formally superseded by Australian Defence Doctrine Publication 00.1 (ADDP 00.1), Command and Control, on 27 May 2009. ${ }^{18}$

Nevertheless, at this time subscription to the philosophy of mission command as an operational command and control construct was well established within the Australian Army. At the time Land Warfare Doctrine 0.0 (LWD 0.0) Command, Leadership and Management prescribed mission command as the Army's extant philosophy of command and control system for the conduct of operations. In advocating the wellestablished tenets of mission command, it specified that subordinates were to be given a clear indication of their commander's intent-the result required, the task, resources and any applicable constraints-but the subordinate commander was to be afforded freedom to decide how to achieve the required result. ${ }^{19}$

Equivalent doctrine and practice was also operative among the various nations commanding and controlling operations in Iraq, most notably the US and British contingents. The Australian concept of mission command had been closely modelled on equivalent US and UK doctrine, and was therefore consistent with Multi-National Force - Iraq (MNF-I) and Multi-National Division - South East command and control systems. MNF-I and MND-SE mission orders were developed and executed on the basis of the tenets of mission command familiar to Australian military forces. All the Australian commanders throughout this period readily acknowledge that the philosophy of mission command was applied as the capstone command philosophy in the development of their operational and tactical mission orders.

17 Australian Defence Force Joint Operational Command and Control, Provisional Edition, Commonwealth of Australia, 14 December 2001.

18 Australian Defence Doctrine Publication 00.1 (ADDP 00.1), Command and Control, formally introduced mission command as applicable to the ADF, stating: '[T] he ADF has adopted a command philosophy known as "mission command" that promotes flexibility by rewarding initiative, ingenuity, innovation, resourcefulness, and devolution of authority in achieving the commander's intent. Understanding the strategic and operational context within the joint operational framework allows tactical commanders to react quickly and appropriately to demanding situations.' ADDP 0.01, Command and Control, para 2.18, p. 2-8.

19 Land Warfare Doctrine 0.0, 'Command, Leadership and Management', Department of Defence (Australian Army), Canberra, 17 November 2003. 
Similarly, Australian commanders unanimously confirm that during the conduct of pre-deployment training, mission command was empowered and employed, including the development and execution of operational orders. Following the original AMTG-1 deployment, extant operational orders from higher coalition headquarters in Iraq were always made available, allowing the deploying force to develop its derivative operational orders. These coalition mission orders had all been 'vetted' and approved by Australian national commanders at the theatre command level. While some specific caveats on such issues as national rules of engagement and compliance with specific international and domestic legal considerations were widely acknowledged and accepted by coalition commanders, no task or battle group commander could recall any specific operational caveats placed upon any missions or tactical objectives assigned to them by Headquarters MND-SE.

These factors suggest that all the essential precursors for the effective application of mission command were functionally in place for Australian forces, particularly given that the campaign in Iraq was predominantly a land component operation with army commanders in command at coalition and Australian strategic, operational and tactical levels of command. Accordingly, it is clear that the underpinning philosophy for command and control in Iraq was in fact mission command; that is, the superior commander would direct what was to be achieved while leaving the subordinate commander free to decide how to achieve the assigned tasks. ${ }^{20}$

The experiences of many task and battle group commanders was that this was variably practised, with different levels of application depending upon the command style and approach of respective national commanders. Given Palazzo's assertion of strong politico-military unity, leading to potentially invasive strategic control at the tactical level, I therefore sought the views and experiences of Australia's task and battle group commanders in terms of understanding how three essential elements of mission command were applied in practice during their deployments. My enquiry centred on three broad questions: first, whether the national strategic intent was clearly conveyed to them; second, whether this allowed them to reconcile potentially divergent Australian and coalition tactical requirements; and

20 ADDP 0.01, Command and Control, para 2.19, p. 2-8. 
third, whether the exercise of Australian national command affected their ability to apply mission command in seeking to achieve both coalition and national objectives.

What follows are select snapshots of the experiences of several of Australia's tactical commanders in an attempt to reconcile Palazzo's assertion of strategic success with the suboptimal conditions experienced in the application of mission command on the ground. I have sought to understand whether the Australian philosophy of mission command was actually applied, and, if it were effectively applied under these conditions, whether it might have contributed to the successful strategic outcome described in Palazzo's study.

In correlating their experiences, it appears that the unreliable transmission of national or strategic intent through the layers of command might also have affected the ability of the Australian national commander in theatre to exercise cogent national command. This observation is based mostly on my personal observations, where wide variations in the interpretation of national intent between commanders at strategic, operational and tactical levels were frequently encountered. By way of example, in one illuminating personal exchange between myself, commander JTF 633 and CJOPS during the latter's visit to $\mathrm{OBG}(\mathrm{W})-2$ in theatre, glaring differences in the interpretation of my authority to intervene to support coalition forces in contact illuminated an embarrassing level of confusion as to my command authority.

COMD JTF 633 had previously instructed me that I was not authorised to intervene on behalf of coalition forces in contact without his express authorisation. It remained a point of contention between us throughout my deployment, as I constantly contested his interpretation of my authorities based upon my pre-deployment training and understanding of previous task and battle group standard operating procedures. Given this dispute, I took the opportunity to confirm this with Australia's theatre commander during his visit. In confirming that this was-in fact-within my authority (the fact that I had even asked greatly aggravated COMD JTF 633), CJOPS stated that my authority to intervene in support of coalition forces in contact extended to combat operations in support of British elements in the adjoining and highly dangerous MND-SE provinces of Basra and Maysaan. This revelation stunned COMD JTF 633 and myself, as this was never considered within the authority of either of us, and seemed contrary to the implied national intent to focus on 
reconstruction and training tasks and avoid combat. Our interpretation had been that a request of this nature (crossing provincial boundaries) would require express governmental authorisation. ${ }^{21}$ Irrespective of the correct interpretation, to my mind the dissonance between we three commanders at respective levels of command (strategic, operational and tactical) was a seminal example of prevalent deficiencies in the articulation of command intent through the Australian chain of command during Operation CATALYST.

This, and the previously recounted experiences of other tactical commanders, suggest that the articulation of intent-the doctrinally essential precursor for the effective application of mission commandwas frequently absent or at best episodic. In seeking to understand the reasons for this during our discussions, given the relatively mature understanding and subscription to the tenets of mission command within the Army at the time, most tactical commanders put forward a variety of speculative explanations. These included either operational immaturity in the Australian operational command chain, individual failings by particular national commanders, or a relatively laissez-faire sense that articulation of Australian intent could be achieved through vetting of coalition operational orders.

The most concerning explanation put forward by several commanders and some of their battle staff was a sense that Australia's most senior strategic and operational commanders simply did not want to articulate Australia's calculated strategic intent formally, as described by Palazzo, because of its political sensitivity:

[Of] second importance to Howard was the opinion of the Australian domestic audience and he recognised the necessity of minimising casualties. In this the Prime Minister successfully managed a potentially divisive issue. Events in Iraq, by comparison, were considerably less important to the achievement of Australia's policy goal. ${ }^{22}$

21 The rationale for this was that an arrangement existed between Australian and British forces whereby mutual support would be provided between provinces where the respective nation's forces were in danger of defeat. In order for the task group or battle group to be able to rely upon support from the British, it would need to be responsive to requests from British forces in Basra and Maysaan provinces. This determination that a decision to deploy to another province to support British forces in heavy contact was within the battle group commander's authority was dubious, given the implied caveats on battle group operations in so many other respects.

22 A. Palazzo, 'Assessing the war in Iraq', Address to the Royal United Services Institute of New South Wales, 31 July 2012, p. 15, www.rusinsw.org.au/Papers/20120731.pdf (retrieved 31 March 2020). 
To have overtly communicated this type of political consideration to the tactical level would risk its public disclosure, resulting in political embarrassment and undermining efforts to buttress the alliance. While limited combat exposure by Australian forces might have been widely suspected within the coalition, in the absence of formal orders to this effect, it remained plausibly deniable. Confirmation of any belief that Australian military forces were only there to 'put a flag in the sand', and nothing more, in order to shore up the alliance would likely prove an embarrassing revelation for the government and Australia's military leadership and soldiers. Formal correspondence illuminating the calculated nature of Australia's military involvement could also wound the strategic enterprise. Some commanders and staff suggest that given the experience and professionalism of Australia's senior leaders, it might also have been that they were embarrassed in being privy to a mission in which Australian troops were committed to a dangerous and complex operation where their freedom of action to achieve the coalition intent was so heavily and deliberately constrained.

If this more calculated approach to preserving the sanctity and secrecy of the national strategic intent is taken to be credible, or even possible, then it would strike at the heart of one of the most essential tenets of mission command: the clear articulation and understanding of higher intent at the tactical level. If it was not possible to bring tactical commanders into the tent' in terms of the true strategic intent and sensitivity to casualties, it would therefore be necessary to constrain tactical activity in order to ensure that pursuit of coalition tactical outcomes would not threaten the sanctity and integrity of the national political intent to demonstrate commitment without suffering casualties.

\section{The impact of constraining tactical freedom of action}

Australian Army doctrine operative at the time highlights two essential components of the operative philosophy of mission command: (1) commanders using a minimum of control so as not to limit the subordinates' freedom of action unnecessarily; and (2) subordinates deciding for themselves how best to achieve their missions. ${ }^{23}$ Given the

23 Land Warfare Doctrine 0-0, 'Command, Leadership and Management', chapter 2, section 2-2, 10 June 2008, para 15. 
limited and episodic articulation of strategic intent previously outlined, and the lack of any real and express limitations on a tactical commander's freedom of action through formal national orders, what remains untested are assertions that tactical freedom of action was deliberately constrained through the national command chain, in particular by the Australian national commander located at HQ JTF 633 in theatre.

In seeking to determine whether the Australian national command element in theatre enabled or undermined mission command, the task and battle group commanders cited a variety of different experiences. The commanding officer of AMTG-1 recalls that the Australian embedded staff officer at Headquarters MND-SE was excellent for advice, and that the commander of JTF 633 was also generally very helpful. His experience with other Australian headquarters at the operational level outside theatre was generally less positive. In stark contrast, the commanding officer of the second AMTG was scathing of the interference of the Commander JTF 633 in unnecessarily constraining his tactical freedom of action to achieve designated and endorsed mission outcomes:

When we did receive [national command] guidance it was ad hoc and always centred on stopping us from doing something. First example - the Brits had responsibility for providing security assistance to the Iraqis for the December 2006 elections. It was in all our interests to coordinate and assist in this regard. We were told via [national command] we had no role and were to stay out of it. I attended the British lead planning meetings and contributed what we could by just advising how we would conduct our normal security roles, which would assist 'naturally', but it was a professionally humiliating time for us. Another examplewe received what was assessed by the intelligence agencies to be credible intelligence that we would be hit by an improvised explosive device on one of the routes within the tactical area we were responsible for. We planned an operation to interdict it. The Land Commander found out and denied us this action and insisted the British execute it, despite the threat fitting within our remit and emanating from our area. I was mortified ... it was so embarrassing in that it was professionally humiliating and a part of my respect for our organisation died that day. ${ }^{24}$ 
I recall numerous and similarly invasive interventions by the Australian JTF 633 commander during the deployment of the OBG(W)-2. After a period, these interventions caused me to question not only the basis of the authority of the national commander to intervene in my tactical decision-making, but also his tactical competence in seeking alternatives to the courses of action being proposed.

By way of example, within a week of the OBG(W)-2 arriving in the province, Jaysh al-Mahdi launched a coordinated and heavy attack on the Police Headquarters in As-Samawah when the police refused to accede to demands for prisoner release. Surprisingly, and reassuringly, for the first time the local Iraqi police and army elements combined and cooperated to defeat this attack. The militia returned in numbers, bolstered by insurgent fighters from other provinces, and laid siege to the provincial headquarters. The situation in the city became dire; the Iraqi Security Forces were both outgunned and outnumbered, so the local commanders called us for combat support and an urgent resupply of ammunition. I was fully aware of our restrictions on intervention - at best we could arrange for an aerial resupply of ammunition. But I resolved to move the battle group tactically to a secure location in the desert just outside the capital. This was not to intervene in the fight but to create a ruse to deceive the insurgents that we were in fact about to commit in support of the Iraqi Security Forces, to unsettle the militia and bolster the confidence of the local Iraqi commander. Whether the ruse was successful or not remains unknown. Either way, the Iraqi Security Forces remained steadfast and the militia eventually withdrew without achieving their objective.

When I informed the JTF commander later that night that I had done this, he was apoplectic, insisting that I had intervened in express contravention of both national and coalition orders. His assertion was-and I recall this precisely-that I did not have the authority to 'step up' the battle group, which required his express permission as national commander. This flabbergasted me. If I could not even manouevre my force without his permission, what tactical authority did I possess as battle group commander? In seeking to clarify command options available to me in future, I recounted an exhaustive list of actions we had been instructed on and trained for on the Mission Rehearsal Exercise, including actions that previous task and battle groups had frequently undertaken in theatre. Each was serially rejected as being outside my remit, including even the option of aerial overpasses by coalition aircraft or authority to observe 
engagements via our unmanned aerial vehicle. With command caveats of this nature, mission command had clearly given way to directive control of tactical activity.

The commanding officer of the second AMTG recalls similar invasive episodes with HQ JTF 633 during his deployment, leading him to conclude:

[HQ] JTF 633 was just a conduit for getting reports out and acting as the scout for Big Brother. I realised very early to play it 'grey' and stay under their radar or invite the 10,000-kilometre screwdriver. I was lucky to have great individuals as respective national commanders during my time as they understood and applied mission command and gave me freedom of action. They were cut from the same cloth, and I was fortunate in this respect. Both applied mission command and both were very supportive. So, I was free to plan and conduct tactical level operations so long as I kept things low profile. To this day, I can only shudder at the thought of the meddling and obstacles I would have experienced if the operation had been more kinetic. ${ }^{25}$

This inconsistency in variable involvement of the national commander in tactical decision-making proved puzzling to many commanders, as did the roles and remit of other embedded national officers in coalition headquarters. The commanding officer of AMTG-2 recalls:

We also had a colonel senior national representative (SNR) embedded with the British Division based at Basra. I had no formal instructions as to how this individual featured within our command and control chain. On national command issues I worked directly to [Commander] JTF 633. I was more of the understanding the embedded SNR was [Commander] JTF 633's representative in Basra with no direct authority in my chain of command. I had little contact with the SNR because I didn't feel a need to engage them and to their credit, they didn't try and impose themselves upon them. But in knowing them personally, I also knew they were available to me if I wanted to engage them informally. ${ }^{26}$ 
Given the variable nature of experiences with the Australian national commander in theatre, it would seem that much came down to the personality of the individual and their corresponding interpretation of the role of the national commander and their role in preserving Australia's strategic intent. While many acted in what was described as an impediment to mission command, through an expressed requirement to 'approve' task and battle group operational orders and activities, others maintained more of a mentoring and enabling role for the tactical commander. Different tactical commanders also recount varied tolerances for risk with their respective national commanders, giving rise to markedly different stipulations on reporting tactical plans on an ongoing basis.

These variable experiences recounted by tactical commanders in terms of the freedom of action granted does not necessarily support the assertion of strategic micromanagement of tactical activities as suggested by Palazzo. Most tellingly, no task or battle group commanders recall any explicit intervention by the Chief of Defence Force acting as personally as a 'strategic corporal' in their tactical decision-making. The most deleterious interventions in tactical decision-making recalled by all tactical commanders were always exercised at the operational level through the national command element, usually by the Commander JTF 633 himself.

However, the varied experiences certainly tend to suggest either a lack of clear articulation or strategic intent and/or national caveats down through the national command chain, or alternatively a willingness by some national commanders to loosen the reins and allow tactical commanders freedom to manoeuvre. Clearly, one of the key bases driving the approach of the national commander towards allowing or constraining the freedom of action of the task or battle group commander was the relationship of trust between them.

\section{Trust}

Australian and Western military doctrine also posits that for the tactical commander to be able to exercise judgement and freedom of action in achieving this higher intent, an essential enabler is trust. That is, once the senior commander has articulated the results to be achieved and assigned the appropriate resources, he/she must have trust in both the professional understanding and ability of the subordinate commander to be able to achieve the outcome desired. Again, in light of Palazzo's assertions of 
close strategic supervision bordering on tactical micromanagement, I also sought to determine whether the prerequisite level of trust was afforded to task and battle group commanders to properly enable mission command at the tactical level.

It is important to note that trust between military commanders engaged in operational activity is always a two-way relationship. Western military doctrine insists that mission command requires a high level of mutual trust at all levels of command. Subordinates are trusted in the allocation of sufficient resources to carry out their missions, and commanders are trusted to keep control to a minimum so as not to constrain their subordinates' freedom of action to achieve their intent. The inverse is that commanders will rely upon subordinates to provide accurate and timely information to achieve operational success. Hence, doctrine highlights that high demands are made on the leadership qualities of subordinates, on their initiative and on their sense of responsibility to carry out assigned tasks. ${ }^{27}$

Once again, great variability in the experiences of respective task and battle group commanders is registered in relation to the sense of trust afforded them and their trust in their senior command chain. The commanding officer of AMTG-3/OBG(W)-1 recalls:

\begin{abstract}
Both Commander 1 Division and Commander 3 Brigade were clear in their discussion with me prior to deploying about the political sensitivities but neither were prescriptive in their guidance, showing great faith and trust. The Brigade Commander completed a reconnaissance concurrent to mine (covering off on the strategic and theatre issues) and we debriefed him on our appreciation while heading home out of Kuwait. He gave guidance but knew from his previous experience at US Central Command Forward and also with INTERFET that guidance would remain fluid and that if we didn't stay a bound ahead in our thinking then we would be caught flat-footed. ${ }^{28}$
\end{abstract}

27 ADDP 0.01 stipulates that 'The ADF's mission command philosophy is realised in the commander's confidence in delegating responsibility to subordinates, and the professional discharge of those responsibilities of command by subordinates. This is of particular importance in response to fleeting windows of opportunity during the conduct of operations, and contingencies where no specific direction has been given to the subordinate.' ADDP 0.01, Command and Control, para 2.31, p. 2-12.

28 Discussions with author. 
Conversely, the relationship between myself and the Commander JTF 633 in theatre was marked by an absence of mutual trust. Given the earlier exchanges on differences in perceived authorities, based upon the expressed stipulation that all battle group operational orders were to be vetted by the national commander, by late in the deployment we were selectively providing redacted operational concepts of operations and operational orders to HQ JTF 633. From discussions with his staff, it was also evident that his relationship with his own staff was similarly affected by a lack of trust and regard. I had determined some protocols with the Chief Operations Staff Officer (J3) at HQ JTF 633 by which sufficient information could be provided to inform the national commander of our tactical activities without invoking his suspicion or tripping his risk sensitivities. I had lost confidence in his tactical acumen, and was failing on most occasions to articulate tactical ideas, concepts or options without attracting his ire. Instead I chose to seek counsel, advice and mentoring on the merits and appropriateness of proposed tactical operations with my parent brigade commander back in Australia. I felt very strongly that our relationship and the constraints being imposed on my tactical authority were jeopardising the lives of $\mathrm{OBG}(\mathrm{W})$ soldiers. This was confirmed in my own mind during one particular incident late in the deployment.

During an indirect fire (rocket) attack on the base, the insurgents fired a second salvo from the exact same point of origin at the 30-minute mark, which was instructive that (1) they knew our protocols (i.e. all clear after 30 minutes), and (2) they were confident that there was going to be no response from us to clear or contest the firing site or point of origin after the first salvo. I believed the latter had come to pass because we had had several previous exchanges with the Commander JTF 633, who insisted that our job was not to seek engagement with the enemy nor was it to protect the base. If a response to indirect fire attacks was required, his view was that the Americans or another contingent should do it—even though one of our approved mission tasks was to patrol suspected indirect fire sites within our designated security area outside the base.

This incident emphasised that his risk aversion was proving highly detrimental to our own force protection, and having to vet immediate tactical action through the national chain of command was untenable. In this case I was unable to convince Commander JTF 633 that aggressive patrolling and/or clearance of launch sites was actually a self-defensive measure, an action to protect ourselves, and I was not - as he suggested'under the spell of the Americans'. I clearly remember at this point convening 
a 'war counsel' with my senior staff officers and combat team commanders on this issue, at which point we resolved deliberately to withhold future patrolling plans from him on the basis that to do otherwise might cost Australian lives and continue to adversely affect Australian morale and reputation on the base. This exchange conclusively demonstrated that there was simply no vestige of mutual trust and that I had lost all respect for his tactical judgement of our situation from afar. I required another mentor, with whom I had professional trust and respect, to discuss tactical options and to ensure that I was acting in accordance with what I perceived to be the 'national interest' and derivative mission orders.

The commanding officer of AMTG-3/OBG(W)-1 had what could only be described as a diametrically opposite experience, with both national command chains forward and rear:

[National Command] worked as well as it could, and worked because they supported us and didn't interfere. The national commander was an excellent mentor and supporter. As I have said before, I put this down to his operational command experience. ${ }^{29}$

Every tactical commander remains adamant that the doctrinal philosophy of mission command was entirely appropriate for the complex operating environment in which we operated, including the complexities concomitant to coalition operations. None recall any suggestion or discussion within the Australian chain of command that the philosophy of mission command would be relevant only to a high-end war-fighting environment and inappropriate for security and stability operations. In fact, its pointed relevance to the current operation inspired the commander of the first AMTG to publish an article on the application of mission command on his return to Australia, in which he emphasised the centrality and applicability of mission command to Operation CATALYST. A central observation was that the effective application of mission command demanded more than rhetorical subscription to the doctrine:

The key to effective, focused action is mission command. The philosophy of mission command must be believed and nurtured. To be effective, it must be built on the intellectual components of clear intent, trust and accountability. The central moral 
component is trust. A physical framework must also be established to support decision-makers at every level, especially those in the midst of chaos and in close contact with the adversary. ${ }^{30}$

Yet despite this seemingly universal subscription to the relevance and utility of mission command, dissonance appears evident in its application within the Australian national command in Iraq. The personal experiences of respective Australian tactical commanders reveal common dynamics at play in seeking to apply mission command in operational practice. Their recollections and observations give rise to familiar revelations about the relevance, effective application and ultimate utility of mission command in modern, complex operations. Most peculiarly, the Australian experience on Operation CATALYST highlights contemporary challenges in fully enabling mission command as a theatre framework providing connectivity and between the strategic, operational and tactical levels of war. This experience is reflective of the issues faced by Western military forces on modern operations, which might be highly politicised and conducted by individual nations within a complex coalition architecture.

\section{Counter-intuitive outcomes}

In another article, 'The making of strategy and the junior coalition partner: Australia and the 2003 Iraq War', Palazzo argues that the Iraq campaign was a masterstroke of Australian policy-making. ${ }^{31}$ His previous assertion that it had little to do with events in Iraq is an intriguing observation for those who deployed, seemingly inimical to the traditional military view that in war, strategic success emanates from successful actions or military 'victories' at the tactical and operational levels of war.

Palazzo's hypothesis is antithetical in contending that achievement of coalition military objectives was neither the principal aim nor ultimate determinant of Australian strategic success:

Unusually, strategic calculation was at the forefront of the Australian Government's senior political leaders and their military advisers. The Australian Government of Prime Minister John Howard saw

30 R. Noble, 'The essential thing: Mission command and its practical application', Australian Army Journal, vol. 3, no. 3, 2006, p. 124, researchcentre.army.gov.au/sites/default/files/aaj_2006_3.pdf (retrieved 31 March 2020).

31 Palazzo, 'The making of strategy and the junior coalition partner', pp. 27-30. 
the War in Iraq as an opportunity to advance a long-held security objective, one that had little to do with events in the Middle East. For Australia, the policy goal for its participation in the Iraq War was the opportunity to enhance its relationship with the United States. In achieving this objective Australia identified factors by which a junior coalition partner can set and attain its own policy goals, and, importantly, avoid creating a conflict with the objectives of the coalition-leader. ${ }^{32}$

Palazzo suggests that tactical 'victories' were neither necessary nor encouraged by Australia's strategic leaders. The mere presence of Australian forces would be sufficient to achieve the desired strategic objectives, provided that tactical involvement was carefully orchestrated and controlled to prevent any semblance of tactical 'defeat'. Task and battle group actions would need to be carefully controlled to ensure strategic visibility while minimising the force protection risk. This complex formula necessitated clear unity of purpose between government and the military in order to achieve the desired strategic outcome:

Australian political-military divisiveness was not evident in the Iraq War. Howard and his senior general, the Chief of Defence Force General Peter Cosgrove (and later Air Chief Marshal Angus Houston), acted as one in regard to Iraq. Cosgrove understood the government's purpose and worked towards that goal. To keep the ADF on target the CDF tightly controlled the mission and kept the Prime Minister informed of its progress. Contemporary military theory contains numerous references to the effect of the 'strategic corporal'. In Iraq the influence of the junior ranks was minimal as Cosgrove aspired to be the 'tactical general'. Throughout the Iraq War no issue was too unimportant for the CDF's strategic-level oversight. The commander of Australia's headquarters in the Middle East also served as Cosgrove's strategiclevel theatre representative. He had direct access to the CDFoutside the formal chain of command — and kept Cosgrove alert to all activities across the Coalition that might have an effect upon Australia's ability to secure its goals. ${ }^{33}$

This strategic scrutiny and control of tactical freedom of action often had debilitating effects on morale at the task and battle group level. The policy of constraining tactical activity at the strategic and operational levels

32 Palazzo, 'Assessing the war in Iraq', p. 13.

33 Ibid., p. 14. 
without national context confused Australian soldiers as well as their higher coalition headquarters in theatre. Without a cogent explanation for curtailment of tactical activity, coalition forces frequently interpreted these inexplicable constraints as a lack of courage and resolve. Irrespective of strategic interpretation, this also generated a highly counter-intuitive but easily foreseeable result: the Australian Army's professional credibility and standing as a trusted, capable and committed alliance partner often suffered at the tactical level. Perceptions of risk aversion to casualties had a gravely deleterious impact on the reputation of Australian forces on the ground.

This trend was visible even before assumption of operational overwatch activities in the more dangerous province of Dhi Qar. During the AMTG period, Professor John Blaxland registered and reported a growing sense of disquiet developing among Australian soldiers and coalition partners in Al Muthanna Province, most particularly within the British contingent. This disquiet morphed into open hostility in later evolutions where tactical freedom of action to intervene in support of coalition forces in contact was constrained, becoming the root cause of verbal disdain for Australian forces:

As one Australian officer observed, British senior officers 'understood' the constraints of the Australian rules of engagement. But the British soldiers, 'the squaddies, called the diggers cowards to their faces. At least some of the diggers agreed.' The net effect of this government-driven tactical approach was the absolute minimisation of Australian casualties. But this approach came at a price in terms of credibility with Australia's allies and coalition partners and soldier's morale. ${ }^{34}$

\section{Final thoughts}

Ironically, Operation CATALYST has proven true to its operational nomenclature (title), although it is far more likely in buttressing the Australian-US alliance at minimal political and human cost (battlefield casualties) rather than a catalysing impact on the Iraqi nation-state and regional geopolitical landscape. Whether it had this latter effect is a separate question not addressed by this chapter. Of greater importance,

34 Blaxland, The Australian Army from Whitlam to Howard, p. 242. 
as evidenced by discussion and debate during the 'War in the Sandpit' seminar, is that it seems to have polarised opinion among political, academic and military commentators as to the most appropriate measure of appraising success.

There is, however, an alternative perspective: at the tactical level, many officers and soldiers viewed this operation as a confusing, disappointing, deeply embarrassing and professionally disheartening experience. For many, our ability to put our hands on our hearts and declare unequivocal mission success remains an elusive and deeply soul-searching endeavour. To the casual observer, this might sound odd, given that many contemporary measures of operational success were present, no soldier was killed in action, and our casualties were often minor despite some intense engagements with opposition forces. Surely this would tend to connote that strategic success was built upon highly professional efforts and outcomes at the tactical level.

The observations outlined in this chapter suggest the means by which Australia's strategic leaders chose to achieve the desired strategic outcomes actually mortgaged professional pride and military reputation at the tactical level. Australia's national command and control architecture contributed to debilitating strategic-tactical dissonance, through either a conscious or an unconscious failure cogently and reliably to communicate strategic (national) intent down to the tactical level of command in a complex coalition operating environment. This did our soldiers a massive disservice in that it returned counter-intuitive results in giving justifiable cause to a cadre of coalition officers and soldiers, and likely also Iraqis, to appraise Australian contingents as 'talking the talk but failing to walk the walk'. I have no doubt that we could have done better in this regard while still achieving the strategic objectives desired by government. We simply needed to be true to our capstone operational doctrine of mission command.

In suggesting this, I remain aware of the dangers of binary thinking. That is, with the benefit of hindsight it is easy to identify the disadvantages of a particular approach, leading to the trite assertion that a different approach would generate a better outcome. My peculiar advantage in this respect is being able to look back with the benefit of the great contextual analytical work by Professor Palazzo and others. Having now also occupied a number of different positions at tactical, operational and strategic levels 
of command, I have a more informed perspective of the difficult and competing interests and issues at play and therefore the strategic context within which the various task and battle groups operated.

Even so, I would still strongly contend that this manifestation of national command control cannot be considered an optimal means by which to wage war, enforce the peace or deliver humanitarian assistance or disaster relief. To prevent strategic-tactical dissonance, and the accompanying deleterious impact upon the morale and well-being of a deployed force, our strategic leaders must strive to get the national command and control architecture right, both in form and in substance. This demands an honest, considered and principled approach to the application of mission command to ensure that those at the most risk on the battlefield understand precisely what it is that they are being asked to do and what they are risking their lives to achieve. This starts with a clear and honest articulation of national intent being cogently communicated down to, and understood by, tactical commanders.

My personal belief is that the means by which we as a military chose to deliver the political outcomes demanded by government on Operation CATALYST did not keep faith with our history, traditions, doctrine or national character. The arguably duplicitous approach we took as a nation to committing our troops to stability operations in Iraq, ostensibly to put an Australian flag in the sand in support of our major ally, generated mixed and equivocal results - some very good (mostly at the strategic level) but many very bad (at the tactical level). This chapter should not be interpreted as suggesting that we should be a reflexive slave to any particular operating methodology, but my view is that we should always understand the reason for taking a different line or treading a different path. We should also understand the potential second- and third-order consequences inherent in any departure from proven doctrinal approaches. To my mind, this is what the 'War in the Sandpit' seminar has allowed me to do: articulate some hitherto unseen or vaguely perceived negative consequences of suboptimal national command and control on a contemporary coalition security and stability operation.

If we do in fact wish to achieve articulated strategic intent, as in this case to buttress and enhance our strategic alliances, and be seen to deliver on our commitment to a rules-based global order, we must ensure that our actions truly reinforce that intent at every level. As a professional military we owe that to ourselves, to our government and - most importantly-to our soldiers and their families. 
This text is taken from Niche Wars: Australia in Afghanistan and Iraq, 2001-2014, edited by John Blaxland, Marcus Fielding and Thea Gellerfy, published 2020 by ANU Press, The Australian National University,

Canberra, Australia.

doi.org/10.22459/NW.2020.06 